\title{
"HOLDINGIZATION" OF THE AGRICULTURAL SECTOR OF UKRAINE: CONSEQUENCES AND WAYS OF THEIR PREVENTION
}

\author{
Lubov Moldavan', Olena Pimenova ${ }^{2}$ \\ ${ }^{1}$ Prof., Doctor of Economics, Honored Economist of Ukraine, Chief researcher of the Department of Forms and \\ Methods of Management in Agri-food Complex of SI, Institute of Economics and Forecasting of National Academy of \\ Sciences of Ukraine. Panas Mirny str., 26, Kyiv, Ukraine. Email: Imoldavan@ukr.net \\ ${ }^{2}$ Assoc. Prof., Ph.D. Taras Shevchenko National University of Kyiv., Vasylkivska str., 90A, Kyiv, Ukraine. Phone: \\ +380984541206, Email: olenapimenova@gmail.com
}

Received 2903 2021; Accepted 13042021

\begin{abstract}
The aim of the study is to investigate the motives of industrial and trade capital in agricultural sector and the consequences of "holdingization" of an agriculture as well as to substantiate main components of the institutional and legal environment aimed at preventing globalization of land use in national agriculture. The following methods were used: monographic (analysis of the distribution of agricultural enterprises by the area of agricultural land); comparative analysis (features of globalization processes in land use); empirical (on a comprehensive assessment of social and environmental consequences of the concentration of large tracts of agricultural land in hands of agroholdings); abstractlogical. Due to the weakness of state structures in Ukraine, the lack of their position on the type of farming as the basis of the agricultural system, unregulated circulation of agricultural land is developing of quasi-agroholding commercial structure of production, accompanied by global transformation of agricultural land use, soil-depleting, intensification of migration and other negative processes. It requires the state regulation of the distribution of agricultural land between economic entities, restricting access to land of non-agricultural companies and greening of land use, which together is an important factor in preventing of the formation of oligarchic-latifundist management system in agriculture of Ukraine.
\end{abstract}

Key words: quasi-latifundism; land use; rural areas; institutional environment.

JEL codes: Q100, Q130, Q150.

\section{Introduction}

In the theory and practice of agrarian economics, schools of two directions have historically opposed each other. The first is formed by representatives of the general political economy, who believe that agriculture is an organic component of the general capitalist system, and its development follows to the same direction as industry. Accordingly, the agricultural enterprise is a capitalist organized structure, the purpose of which is to obtain the highest income. Representatives of the second trend, from the founders of agrarian economy as A. Teyer, J. Tyunen, T. Brinkman to their current followers, argue that agriculture is only partially "reflects" the general capitalist political economy (Shanin, 1990). It has features that makes it impossible for an agricultural enterprise to be a purely commercial structure: “... Where nature prevails, there is no rational (in the sense of the greatest savings and productivity of results) organization of production" (Bulgakov, 1900). An agricultural enterprise that uses land and other natural resources should be evaluated not only by special economic but also by social indicators (Gross, 1985). At the same time, economic results must be correlated with the ecological balance in order to obtain a truly comprehensive tool for assessing an agricultural activity (Danz, 1972). Socio-environmentally oriented

Copyright (C) 2021 Author(s), published by Vytautas Magnus University. This is an open access article distributed under the terms of the Creative Commons Attribution Non-Commercial 4.0 (CC BY-NC 4.0) license, which permits unrestricted use, distribution, and reproduction in any medium provided the original author and source are credited. The material cannot be used for commercial purposes. 
entrepreneurship can meet only the organizational structures of management, created by rural people who "tend to live with nature" (Thaer, 1830). Such structures are individual family farms and farming corporations of various organizational and legal forms, which form the agricultural system of Western European, North American and many other countries. However, capitalist-organized structures which aimed for the highest profit are represented by transcontinental and national latifundistoligarchic companies, dominating in developing countries and post-Soviet countries like Ukraine, Russia, Kazakhstan and others.

\section{Research methods}

The purpose of the article is to study the motives of industrial and trade capital in agricultural sector and the consequences of "holdingization" of an agriculture as well as to substantiate the main components of the institutional and legal environment aimed at preventing globalization of land use in national agricultural sector, taking into account the experience of countries that have coped with this problem.

To achieve this goal, the following tasks were set:

- to research the experience of forming agro-industrial and trade corporations in agriculture of USA;

- to study main approaches to the formation of agricultural holdings and other business entities for land use in Ukraine;

- to compare and generalize the experience of agriculture in developed countries and in Ukraine and to identify the lessons for Ukraine in order to increase the socio-ecological and economic efficiency of agriculture in terms of sustainable development.

The following methods were used in the research process: monographic (analysis of the distribution of agricultural enterprises by the area of agricultural land); comparative analysis (features of globalization processes in land use in Ukraine, USA, Latin America and Western European countries are determined); empirical (concerning a comprehensive assessment of social and environmental consequences of the concentration of large tracts of agricultural land in hands of national and transcontinental industrial and commercial companies); abstract-logical (generalization and formulation of the main conclusions and proposals based on the results of the study).

\section{Results and discussion}

The history of agro-industrial and commercial corporations in agriculture originates in United States and is known in a scientific literature as the history of "bonanzas" (Drache Hiram, 1964). The motives for the entry of large commercial capital into agriculture were: the desire of partner companies in agriculture for logistics to maximize profits through the direct introduction of scientific and technological progress; opportunities for the processing companies to obtain the raw materials at their cost; preferential taxation of agricultural producers etc. At the beginning of 1970s, according to the US Department of Agriculture, 149 from the 410 largest corporations were engaged in agriculture, 52 were engaged in the production of livestock and the provision of production services to farmers, 57 were engaged in the processing of agricultural raw materials, 64 were engaged in food sales and 88 were engaged in activities outside the agro-industrial complex.

At that time, it was started appeared the socio-ecological consequences of economic and technical integration of food chains into a single structure of food production and agricultural raw materials under the management of large non-agricultural capital, such as: introduction of ruthless competition in agriculture; modernization and more "sophisticated" methods of absorption and operation of agricultural producers; monopolization of large capital of national and foreign food markets and difficult access to family farms; dictation of market prices; overexploitation, depletion and reduction of soil fertility; high rates of reduction of employees, compared to the same process in traditional farms; denaturalization of food 
throughout the vertical food chain (Robbins, 1974).

These and other socio-economic processes have provoked protests from farmers and food consumers. This prompted Kansas, Minnesota, Wisconsin, South Dakota and other states to pass laws against monopolies in agriculture, after which the US government banned non-agricultural firms with a capital of more than $\$ 3$ million and controlling companies with an income of more than 1 million dollars at the federal level to participate directly in agricultural production (Morozova, 1977). Companies were excluded from state support programs for agriculture and strict environmental requirements were introduced.

Under the influence of these and other processes agro-industrial-trade forms of corporatization of agriculture began to gradually "erode", break up into small industry enterprises and firms, change the form of participation or completely stop an agricultural production. In American scientific literature these processes are called "reverse movement from agriculture."

Industrial and trading companies, pushed out of US agricultural sector, have not disappeared. On the wave of Green Revolution, they expanded their activities in Latin American countries. The entry of nonagricultural corporations into the agricultural sector was facilitated by the same factors as in United States, as well as: unrestricted access to land and its cheap price (from $\$ 500$ per 1 ha); cheap labor; fertile lands; support for government agencies etc.

The negative consequences of the colonization of large tracts of agricultural land by non-agricultural capital are reflected in the research conducted in Latin America by Professor A. de Janvry of the University of California (Janvry, 1981). The scientist draws attention to the depleting of land use and threatening the environment, declining the employment in an agricultural sector and low wages (\$ 60-70), landlessness of indigenous peoples and growing poverty, migration of rural population and depopulation of rural areas.

In EU countries, including the new ones, large non-farm capital could not penetrate into an agriculture, as in almost all of them the type of farming was legalized, to ensure strict rules of access to agricultural land. Ukraine, despite its European integration orientation, has not used the European experience. The reorganization of collective and state farms envisaged by the agrarian reform took place during the 1990s. 11.8 thousand of non-state agricultural enterprises were reformed until the year 2000 . On this basis, more than 21.6 thousand companies were established, mainly with limited liability, private enterprises and agricultural production cooperatives.

The formation of agricultural holdings was not provided for the concept of reforming of the collective agricultural enterprises in Ukraine. Moreover, the Decree of the President of Ukraine about the legalization of holding companies in the industries (1994) banned such structures in agriculture. The largest average land plots (2806 ha) were formed in production cooperatives and the smallest (999 ha) were formed in private enterprises (Demyanenko, Cramon-Taubadel von S., 2004)

Formation of economic entities with land use, which, in fact, did not go beyond large corporate farms in United States (average size of the largest farm corporations is 3454 acres or 842 hectares of land (ProQuest Statistical Abstract of United States: 2019), Eastern European countries (average size of the largest farms in Germany - 1686 hectares and others (Situatiausberidit, 2018/19), was considered a positive result. Owners of land shares were the founders of new enterprises, leasing land 
to their farms, remained its employees. Multidisciplinary production and accordingly working places were preserved. At the same time 38.4 thousand farms were operated.
However, in 2003, state statistics recorded 34 enterprises that have already cultivated 10 thousand hectares or more (Table 1).

Table. 1 Distribution of agricultural enterprises of Ukraine by the area (Statistical Yearbook "Agriculture of Ukraine" for the respective years)

\begin{tabular}{|c|c|c|c|c|c|c|c|c|c|c|c|c|c|c|c|}
\hline \multirow{3}{*}{$\begin{array}{c}\text { Agricultural } \\
\text { groups } \\
\text { enterprises } \\
\text { by the area } \\
\text { of land in } \\
\text { their use }\end{array}$} & \multicolumn{6}{|c|}{ Number of enterprises } & \multicolumn{6}{|c|}{ Area of agricultural land } & \multicolumn{3}{|c|}{$\begin{array}{c}\text { Agricultural area land } \\
\text { per enterprise, ha }\end{array}$} \\
\hline & \multicolumn{2}{|c|}{2003} & \multicolumn{2}{|c|}{2010} & \multicolumn{2}{|c|}{2017} & \multicolumn{2}{|c|}{2003} & \multicolumn{2}{|c|}{2010} & \multicolumn{2}{|c|}{2017} & \multirow[b]{2}{*}{2003} & \multirow[b]{2}{*}{2010} & \multirow[b]{2}{*}{2017} \\
\hline & 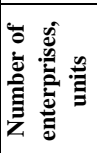 & 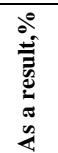 & 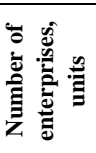 & 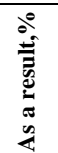 & 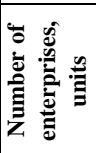 & 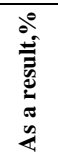 & 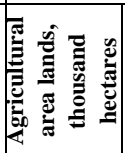 & 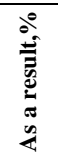 & 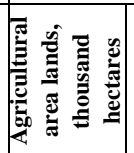 & 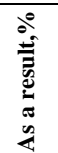 & 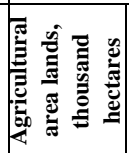 & 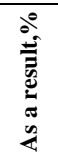 & & & \\
\hline До 5 & 6850 & 11,4 & 5784 & 10,2 & 3138 & 6,9 & 22,5 & 0,1 & 18,3 & 0,1 & 10,1 & 0,1 & 3,3 & 3,2 & 3,2 \\
\hline $5,1-10$ & 4881 & 8,1 & 4038 & 7,1 & 2594 & 5,7 & 38,8 & 0,2 & 31,9 & 0,1 & 20,3 & 0,1 & 7,9 & 7,9 & 7,8 \\
\hline $10,1-20$ & 5787 & 9,8 & 4925 & 8,7 & 3937 & 8,6 & 90,8 & 0,4 & 76,3 & 0,4 & 61,0 & 0,3 & 15,6 & 15,5 & 15,5 \\
\hline $20,1-50$ & 16251 & 27,1 & 13707 & 24,3 & 11263 & 24,7 & 614,5 & 2,6 & 519,8 & 2,4 & 424,9 & 2,1 & 37,8 & 37,9 & 37,7 \\
\hline $50,1-100$ & 5279 & 8,8 & 4831 & 8,6 & 4903 & 10,8 & 355,9 & 1,5 & 345,2 & 1,6 & 354,3 & 1,8 & 67,4 & 74,5 & 72,3 \\
\hline $100,1-500$ & 6512 & 10,9 & 7181 & 12,7 & 7372 & 16,2 & 1589,2 & 6,7 & 1743,1 & 8,1 & 1797,1 & 9,0 & 244,0 & 242,7 & 243,7 \\
\hline $500,1-1000$ & 3119 & 5,2 & 2667 & 4,7 & 2651 & 5,8 & 2282,5 & 9,6 & 1919,4 & 8,9 & 1891,4 & 9,5 & 731,8 & 719,7 & 713,5 \\
\hline $1000,1-2000$ & 3927 & 6,6 & 2661 & 4,7 & 2481 & 5,4 & 5645,5 & 23,9 & 1822,8 & 17,7 & 3570,9 & 17,8 & 1437,6 & 1436,6 & 1439,3 \\
\hline $2000,1-3000$ & 1873 & 3,1 & 1347 & 2,4 & 1084 & 2,4 & 4543,4 & 19,2 & 3295 & 15,3 & 2649,2 & 13,3 & 2420,7 & 2446,5 & 2444,0 \\
\hline $3000,1-4000$ & 942 & 1,6 & 666 & 1,2 & 471 & 1,0 & 3234,2 & 13,7 & 2293,0 & 10,6 & 1635,4 & 8,2 & 3433,3 & 3442,9 & 3472,9 \\
\hline $4000,1-5000$ & 435 & 0,7 & 376 & 0,7 & 276 & 0,6 & 1931,2 & 8,2 & 1670,5 & 7,6 & 1236,1 & 6,2 & 4439,5 & 4442,8 & 4478,6 \\
\hline $5000,1-7000$ & 356 & 0,6 & 332 & 0,3 & 261 & 0,6 & 2052,6 & 8,7 & 1919,6 & 8,9 & 1526,3 & 7,6 & 5765,7 & 5781,9 & 5848,0 \\
\hline $7000,1-10000$ & 91 & 0,2 & 178 & 0,2 & 138 & 0,3 & 743,3 & 3,1 & 1479,6 & 6,9 & 1140,1 & 5,7 & 8168,1 & 8312,4 & 8261,6 \\
\hline Понад 10000 & 34 & 0,1 & 131 & 0,3 & 166 & 0,4 & 495,8 & 2,1 & 2450,9 & 11,4 & 3643,1 & 18,3 & 14582,3 & 18709 & 21946,4 \\
\hline $\begin{array}{c}\text { Total } \\
\text { enterprises and } \\
\text { area }\end{array}$ & 56437 & 94,2 & 48824 & 100 & 40735 & 100 & 23640,2 & 100 & 21585,7 & 100 & 19960,2 & 100 & 418,8 & 226,3 & 490,0 \\
\hline
\end{tabular}

In total, their land use amounted to 496 thousand hectares of land. In 2006, the Law of Ukraine "About Holding Companies in Ukraine" (About Holding Companies in Ukraine, 2006) was issued, in which there was no provision restricting their formation in the agricultural sector, which practically legalized the holding at the industry. Nonagricultural companies appeared, which began to lease and then buy the corporate rights of the owners of reformed farms, creating large integrated structures. In 2010, there were already 131 "tens of thousands", and the area cultivated by them reached 2.5 million hectares. Enterprises cultivating from 7,000 to 10,000 hectares were rapidly increasing their land use. If in 2003 there were 91 of them, in 2010 were 178 units. The area under their cultivation increased from 743.3 to 1480 thousand hectares, respectively. The rest of the groups recorded a decrease in the number of enterprises and the size of their land use. Since 2010, the above processes have deepened significantly. During 2010-2017 the number of enterprises decreased from 48.8 thousand to 40.7 thousand. However, the group with land use of more than 10,000 hectares increased by $21 \%$, and its land use by 3237.4 thousand hectares.

According to the journal "TOP-100 agricultural companies" 16 agro-industrial structures began to control 100 thousand hectares and more. If in 2012 on average, each such company had almost 203 thousand hectares, now is about 240 thousand hectares.

According to researchers from the NSC "Institute of Agrarian Economics", these structures have absorbed or subjugated more 
than 6,000 agricultural enterprises, they control up to $40 \%$ of the land used by enterprises and produce up to a third of agricultural products.

Table 2. Companies with the largest land use in agricultural sector of Ukraine in 2019, ha

(Rating of agricultural holdings of Ukraine 2019 by land bank size from Agricultural Consulting)

\begin{tabular}{|r|l|c|}
\hline № & \multicolumn{1}{|c|}{ The company name } & Area, ha \\
\hline 1. & «UkrLandFarmihg» & 570000 \\
\hline 2. & «Kernel Group Company» & 550000 \\
\hline 3. & «Agroprosperis» (NCH) & 400000 \\
\hline 4. & «Myronivsky Bakery Product» (MBP) & 300000 \\
\hline 5. & «Astarta-Kyiv» & 250000 \\
\hline 6. & «Mria Agroholding» & 165000 \\
\hline 7. & «Agroton» & 151000 \\
\hline 8. & «Industrial Dairy Company» (IDC) & 130000 \\
\hline 9. & «AgroGeneratio» & 120000 \\
\hline 10. & «Epicenter K» & $\approx 120000$ \\
\hline
\end{tabular}

Land banks of agro-industrial and trading companies are characterized by a large territorial dispersion. Thus, UkrLandFarmihg leases land in 22 regions of Ukraine, Ukragroprom leases in 17 regions, Ukrainian Agrarian Investments leases in 16 regions, and Kernel Group Company leases in 11 regions.

The constant desire of companies to increase their land not only by buying the assets of traditional farms with leased land and turning them into subsidiaries, but also by merging or acquiring in whole or in part other companies are the main features of agrohodings. This trend is accompanied by the intensive attraction of foreign capital by companies in the foreign stock market, as a result of which foreigners become owners of a certain part of the corporate rights of such companies. It should be noted that the mother companies of agro-industrial structures largely have foreign jurisdiction.
The term "agroholding" is not defined in Ukrainian economic literature and is used in different interpretations: "agroholding associations", "vertically integrated structures", "agro-industrial and trade corporations", "agri-food holdings", "quasiholdings" etc. These structures are formed and operate without legislative regulation of the base of their activities and statistical accounting.

Globalization processes in land use are accompanied by the transition of companies, followed by a large number of traditional farms in Ukraine to monoculture agriculture, export-oriented, destruction of livestock and other labor-intensive (but important for Ukrainian market) products, displacing up to 1.5 million employed, increasing migration and depopulation of rural areas. Due to the inherent of large commercial capital an intensive soil-destroying and soil-depleting use of agricultural lands in the main exportoriented areas of Steppe and Forest-Steppe, the lands of which are mostly controlled by large corporations, water and wind erosion is

Copyright (c) 2021 Author(s), published by Vytautas Magnus University. This is an open access article distributed under the terms of the Creative Commons Attribution Non-Commercial 4.0 (CC BY-NC 4.0) license, which permits unrestricted use, distribution, and reproduction in any medium provided the original author and source are credited. The material cannot be used for commercial purposes. 
between $50 \%$ and $83 \%$. The coefficient of erosion here is from 1.20 , which characterizes the crisis of soils, to 1.46 , which indicates a catastrophic state of the soil cover of these regions.

Measures aimed at reducing wind erosion and helping to preserve soil moisture require additional funds, in the allocation of which agro-industrial and commercial corporations are not interested.

The desire to obtain maximum benefits with minimal reproduction costs is also characteristic of measures related to the return to a soil of nutrients removed from the harvest is the basic law of simple reproduction of soil fertility (Liebig, 1936). Today, the deficit of nutrients in soils exceeds more than twice the lower ecologically acceptable limit. The deficit of humus is $600-700 \mathrm{~kg}$ per 1 ha. In Steppe and part of Forest-Steppe regions, where the most of the farms are subordinated or absorbed by agro-industrial and trade companies, the application of organic fertilizers is from 0.0 to 0.1 tons per 1 ha at a rate of 8-9 t / ha, straw and other organic remnants are not plowed; steam, green manure, cover crops are absent.

As a result, most of the crop is formed due to natural soil reserves of nutrients, which today, according to soil scientists in Ukrainian chernozems is 2.5-3 times less than in the soils of EU countries. According to their estimates, up to UAH 30 billion should be spent annually in addition to what is being done today to maintain a deficit-free balance of nutrients in a soil (Medvedev, 2015).

Agro-industrial and trade companies are attributed by significant economic advantages, that, however, in addition to high productivity, which is achieved by growing an average of 2 of the most mechanized crops, are questionable. This conclusion follows from the research of individual scientists, rather than official statistics, which are not conducted on the production activities of agricultural holdings. Thus, according to a study by scientists of the NSC "Institute of Agrarian Economics", the profit from 1 ton of products in agricultural holdings was lower compared to traditional farms for wheat by $78 \%$, corn by $38 \%$, sunflower by $80 \%$
(Lupenko, Kropivko, 2013). According to a study of V. Andriychuk and I. Sas, in 20142015 the profitability of wheat in agricultural holdings was on $7-11 \%$ lower compared to uncontrolled farms (Andriychuk, Sas, 2017).

A comparison of economic, ecological and social indicators shows that a small increase in yields in agricultural holdings compared to uncontrolled enterprises does not compensate of low efficiency, social and ecological losses of monoculture production.

\section{Conclusion}

Thus, Ukraine has formed an agricultural system adequate to Latin American countries, which is characterized by the same negative socio-ecological problems that existed before the 1970s in United States and which are now faced by countries where in agricultural system the industrial, trade and financial corporations are dominated.

The above-mentioned processes of agroholdingization of agricultural sector were a consequence of the fact that for the spread of a farmer type of organization of agricultural production in Ukraine was not created and there are no political, legal and economic conditions till the present time.

The legislation does not enshrine the right of land use on the basis of ownership and lease for rural population, who has professional knowledge, skills and works directly in production. Economically feasible optimization of land use (including the lease) as a tool for socially and economically oriented distribution of agricultural land in interests of farms is not standardized. There are no mechanisms for acquiring of land ownership or acquiring of land use rights on a lease basis, which would prevent speculative actions in agricultural land market.

The relevant Laws of Ukraine (On Amendments to Certain Legislative Acts of Ukraine Concerning the Circulation of Agricultural Lands: Law of Ukraine, 2020) do not comply with any of principles of Western European land legislation. On the contrary, they are aimed at maintaining of the current type of agricultural holding in Ukraine's agricultural sector. A comparative analysis of 
an organizational structure of agricultural sector of Ukraine, Western Europe and other countries allows us to formulate several lessons, the assimilation of which at this stage will harmonize to national agricultural policy with the EU Common Agricultural Policy in the context of European integration obligations arising from the Association Agreement between Ukraine and the EU.

The first lesson: agriculture due to its features and multifunctional purpose does not accept the organizational and legal forms of corporations of a purely commercial industrial type. Failure to recognize this pattern leads to social and ecological losses that are not offset by the economic benefits of agro-industrial and commercial companies.

The second lesson: features of agriculture require the legislative regulation of an agricultural system of farmer type of production. The purpose of this act is to formalize the features of agricultural organizational and legal forms and the state policy on each of them separately.

The third lesson: limiting the deepening of agroholdingization in agricultural sector is impossible without: a) restricting land use on the basis of ownership and lease; b) exclusion of agro-industrial and trade corporations from state support programs for agriculture; c) legislative regulation of strict rules of economic, social and ecologically oriented use of agricultural lands, which will prevent monocultural soildepleting production inherent to large commercial capital.

Due to the weakness of state structures in Ukraine, the lack of their position on the type of farming as the basis of the agricultural system, unregulated circulation of agricultural land in agriculture are developing quasiagroholding commercial structure of production, accompanied by global transformation of agricultural land use, soildepleting agricultural management systems with monoculture production, displacement of labor force, intensification of migration and other negative processes, the losses from which for society are not offset by the economic benefits of concentrating large tracts of land in the hands of agro-industrial and commercial companies.

It requires the state regulation of the distribution of agricultural land between economic entities, restricting access to land of non-agricultural companies and greening of land use, which together is an important factor in preventing the formation of oligarchic-latifundist management system in agriculture of Ukraine.

\section{Acknowledgements}

Authors of this research study express gratitude to John Scarratt, native speaker from UK for checking this article for English spelling.

\section{References}

About holding companies in Ukraine. (2006). Law of Ukraine, № 35-28-IV. Access mode: https://zakon.rada.gov.ua/laws/main/3528-15

Andriychuk V., Sas I. (2017). Concentration in the agrarian sphere of economy: problematic aspects: monograph. Kyiv: KNEU, 303 p

Bulgakov, S. (1900). Capitalism and agriculture. Type. and lithograph. by V.A. Tikhanova, T.1., 457. p.

Danz, W. (1972). Sozialfunktionen der Landwirtschaft. Innere Kolonisationen - Land and Gemeinde, 21, 330-333 p.

Copyright ( 2021 Author(s), published by Vytautas Magnus University. This is an open access article distributed under the terms of the Creative Commons Attribution Non-Commercial 4.0 (CC BY-NC 4.0) license, which permits unrestricted use, distribution, and reproduction in any medium provided the original author and source are credited. The material cannot be used for commercial purposes. 
Demyanenko S., Cramon-Taubadel von S. (2004). Organizational and legal forms of reformed agricultural enterprises in Ukraine: what conclusions can be drawn? Agriculture of Ukraine: crisis and recovery, 93-101p.

Drache Hiram, M. (1964). The Day of the Bananza. North Dakota Institute for Regional Students, 93p.

Gross, P. (1985). Okonomie im Ekologischen Landbau-Zusammenhage, Daten, Facten. Ekologischer LandauLandwirtschaft mit Zukunft. Stuttgart, 54 p.

Janvry, A. (1981). The Agrarian Question and Reformism in Latin America. Baltimore, Maryland: Johns Hopkins Universitiy Press, $352 \mathrm{p}$.

Liebig, Y. (1936). Chemistry in application to agriculture and plant physiology. State Publishing House of Collective and State Farm Literature "Selkhozgiz", 401 p. Access mode: by subscription. - URL: https://biblioclub.ru/index.php?page=book\&id=134215

Lupenko Y., Kropyvko M. (2017). Agroholdings in Ukraine and strengthening the social orientation of their activities. Economics of agro-industrial complex, № 7, 5-21 pp.

Medvedev, V. (2015). Land reform and soil fertility. Bulletin of Agricultural Science, №5. 73-79 pp.

Morozova, V. (1977). US agro-industrial associations (organization, management features, role in food production). Nauka, $270 \mathrm{p}$.

On Amendments to some Legislative Acts of Ukraine on the circulation of agricultural land. (2020). Law of Ukraine, № 552-IX. Access mode: https://zakon.rada.gov.ua/laws/show/552-20; On land lease. (2020). Law of Ukraine № 161-XIV. Access mode: https://zakon.rada.gov.ua/laws/show/161-14

ProQuest Statistical Abstract of United States (2019). The National Data Book, 554-555p.

Robbins, W. (1974). The American Food Scandal: Why You Can't Eat Well on What You Earn. New York, 280 p. Shanin, T. (1990). Forms of economy outside the system. Questions of philosophy № 8, p. 111-113.

Situatiausberidit (2018/19). Des deutsdien Bauerystoandes.

Thaer, A. (1830). Fundamentals of rational agriculture. Publ. Shiryaev, 324 p. 